\title{
Biopolitical and Disciplinary Peacebuilding: Sport, Reforming Bodies and Rebuilding Societies
}

\author{
Laura Zanotti, Max Stephenson Jr \& Marcy Schnitzer
}

To cite this article: Laura Zanotti, Max Stephenson Jr \& Marcy Schnitzer (2015) Biopolitical and Disciplinary Peacebuilding: Sport, Reforming Bodies and Rebuilding Societies, International Peacekeeping, 22:2, 186-201, DOI: 10.1080/13533312.2015.1017082

To link to this article: http://dx.doi.org/10.1080/13533312.2015.1017082

曲 Published online: 25 Mar 2015.

Submit your article to this journal 2

III Article views: 194

Q View related articles $₫$

View Crossmark data $\nearrow$ 


\title{
Biopolitical and Disciplinary Peacebuilding: Sport, Reforming Bodies and Rebuilding Societies
}

\author{
LAURA ZANOTTI, MAX STEPHENSON JR and \\ MARCY SCHNITZER
}

\begin{abstract}
The peacebuilding political rationality established in the first years of the current century broadened the target of such efforts from state institutions to populations and adopted an array of disciplinary and biopolitical techniques aimed at changing individuals and the ways they live together. This article explores international organization discourses on sport and peacebuilding and argues that the broad consensus on sport as a peacebuilding strategy is most fruitfully explored in light of the intensification of the biopolitical and disciplinary trajectories of the liberal peace.
\end{abstract}

\section{Introduction}

This article examines increasing scholarly and professional interest in sport as a tool for building peace in the context of a broader reconfiguration of peacekeeping and peacebuilding as disciplinary and biopolitical practices. Our goal is not to provide an assessment of whether sport is 'effective' or 'counterproductive' for peace in the abstract. Such an evaluation can only be conducted in specific contexts. Instead, we here explore the practice of employing sport as a strategy for peacemaking in the broader context of the international community's shift from conceiving peacebuilding as a strategy to maintain the transnational legal order to one of protecting people and transforming the ways they live together. Our work embraces the concern of other scholars, including Fred Coalter, ${ }^{1}$ who have recently situated analysis of sports and peacebuilding within a broader interrogation of assumptions concerning the meaning of 'development' and of the relationships between individual and society such definitions portend. In particular Coalter has critically addressed what he calls 'environmental determinism', that is, 'the assumption that deprived societies inevitably produce deficient people'. ${ }^{2}$ We situate this analysis of sport within a broader critical exploration of the political rationality underpinning current conceptions of peacekeeping and peacebuilding. In particular, we argue that the shift in the United Nations' (UN) conceptualization of peacebuilding as a practice mainly concerned with the stability of international borders and state institutions to one mainly concerned with the safety and security of individuals and social reformation has opened space to include sport among its instruments. We treat the practice of peacebuilding and sport as co-constitutive processes that are by and large mutually reinforcing. We trace the opening of the discursive space that led to the intensification of various international governmental and non-governmental organizations' interest and focus on sports as a peacemaking vehicle in the 
UN to a reconceptualization of peacebuilding. That effort emerged in the new millennium under the guise of the broader umbrella of the doctrines of human security and the responsibility to protect (R2P).

In the 1990s, in line with then United Nations Secretary-General BoutrosBoutros Ghali's Agenda for Democracy, the UN concentrated on reforming state institutions and on encouraging Western style democratic political systems as key instruments for promoting peace and development. In the 2000s, as the Millennium Declaration and then Secretary-General Kofi Annan's adoption of the doctrine of $\mathrm{R}^{2} \mathrm{P}^{3}$ suggested, the focus of $\mathrm{UN}$ peacebuilding initiatives shifted from reforming failing states' institutions to protecting people from a variety of threats to their survival, including violent conflict, government violence, natural disasters and more. Even as UN officials adopted human security as the central legitimizing principle for intervention, 'the people' became the primary target of protection as well as a potential source of threat and instability. In consequence, national populations emerged as the central focus of international initiatives. In this framework United Nations and European Union officials now saw changing the way people lived together and seeking ways and means to provide opportunities for them to shift their behaviours as indispensable for realizing peace and as a necessary complement to reforming institutions. Many NGOs followed suit, embracing the aspiration of building peace from the 'bottom up'. Peacebuilding scholars also broadly shifted their analytical orientation to the grassroots. Investigators increasingly saw the 'local' as a source of human capital for building peace, questioned portraying the targets of peacebuilding as a 'blank slate' and began instead to study the political and social dynamics of societies for their purport for peace. ${ }^{4}$

As officials and academics shifted the focus of peacebuilding from institutions to human security, such interventions became all-encompassing endeavours. The focus on 'people' required the involvement of new actors even as it demanded development of fresh techniques for 'reformation and transformation' of the 'local' body politic. We argue the growing interest in sport as a peacebuilding strategy through 'bottom-up' transformation of conflict societies can be understood as part of an intensification of the biopolitical and disciplinary trajectories of the liberal peace.

Methodologically, we view peacebuilding discourses as 'archives' through which analysts may read the practice of sport as a peacemaking tool. ${ }^{5}$ Foucault conceived of archives as places at which connections between discourses are created or severed and where 'knowledges' are transmitted or allowed to die. ${ }^{6}$ Rather than exploring the 'effectiveness' of normative claims for sport in peacebuilding taken in isolation, we instead map the processes through which sport as a discursive practice has been produced, legitimized and used within the now dominant human security-oriented peacebuilding rationality. We assess sport's role in peace efforts, not on the basis of what its proponents claim it can do, but as a practice whose field of signification and political effects must be understood as part of the discursive practices in which it is situated. Instead of seeking to determine in the abstract whether sport is 'good or bad for peace' we outline how sport is being included in security, peace and democracy discourses. 
In the pages that follow, we first document the UN's increasing interest in sport and highlight several of the interpretations that have been proposed in the academic literature concerning its use in peacebuilding. Thereafter, we explore the broader reconceptualization of peacekeeping and peacebuilding along disciplinary and biopolitical trajectories and interpret the growing interest in sport as a peacebuilding tool in that context. We conclude that the growth of sport as a peace strategy is most fruitfully understood in this way.

\section{The UN, Sport and Peace}

Shortly after adoption of the Millennium Declaration as its guiding document for peacebuilding efforts, the United Nations officially recognized sport's potential to achieve international development goals, as well as to encourage peace in conflict conditions. The world body formalized sport's newfound status as an accepted intervention by creating the position of Special Adviser on Sport for Development and Peace (SDP) to the United Nations Secretary-General in 2001. The UN also formed an Inter-Agency Task Force on SDP in 2002, established the SDP International Working Group in 2004 and designated 2005 as the International Year for Sport and Physical Education. ${ }^{7}$ In 2005, too, the outcomes document of the World Summit on Millennium Development Goals (MDGs) formally recognized sport's possibility for peacebuilding. ${ }^{8}$

An increasing number of actors have joined the United Nations in its embrace of sport as a mechanism to mitigate conflict and encourage peace. International non-governmental organizations (INGOs), such as Right to Play and the Fédération Internationale de Football Association (FIFA), national governments and major corporations have all joined the cause. Additionally, sportanddev.org, the International Platform on Sport and Development, serves an on-line networking function connecting various individuals and organizations from across the world with an interest in the topic. This broad array of actors from all three sectors of the political economy have supported the growth of sport programmes directly targeted to populations and linked to an array of goals, including improved public health, disease prevention, peacebuilding and conflict mitigation, education and gender equality.

In 2003, the UN Inter-Agency Task Force on SDP (noted above) released a report lauding the potential benefits of sport as a development and peace intervention. ${ }^{9}$ The Task Force narrative characterized such initiatives as 'cost-effective' and suggested that as a group they promote beneficial values and goals, including exercise for improved health; greater awareness of the value of education; sustainable development; peace; improved interpersonal communication skills; partnerships between UN, state, international non-governmental organizations and community groups and increased HIV/AIDS awareness. ${ }^{10}$ The UN group also argued sport could play roles in reducing crime and anti-social behaviour, in workforce development by equipping participants with employment-relevant capacities, in empowering women and girls, in building social capital, in preventing social conflict, in rehabilitation and reintegration of wounded or injured 
citizens, in improving societal communication capacities and in securing human rights. ${ }^{11}$

The Inter-Agency Task Force recommended the following steps aimed at attaining this array of potential benefits:

- Improved integration of sport into the development agenda and

- Its incorporation as a useful tool in programmes for development and peace

- Inclusion of sport-based initiatives in the country programmes of United Nations agencies where appropriate and according to locally assessed needs

- Increased attention and resources to sport from governments and the UN system for development and peace programmes

- Adoption of a range of communications-based activities using sport focused on well-targeted advocacy and social mobilization, particularly at local and national levels

- Design and realization of a diverse array of partnerships to implement programmes that employ sport for development and peace. ${ }^{12}$

The 2006 Report of the UN Secretary-General on SDP emphasized sport's potential import for efforts to achieve the MDGs. ${ }^{13}$ Briefly, those aims addressed: extreme poverty and hunger; universal primary education; gender equality and women's empowerment; reduced child mortality; maternal health; HIV/AIDS, malaria and other diseases; environmental sustainability; and encouraging global partnerships for development. ${ }^{14}$ To date, analysts have not assessed the place of sport in securing all of these aspirations. However, the UN Office on Sport for Development and Peace (UNOSDP) has highlighted the roles sport may play in three Millennium Goal areas in particular: Child and Youth Development, Gender and Health. ${ }^{15}$

The United Nations and sympathetic governments and organizations have used sport and athletic competition in a variety of ways since in the name of peace and development and for an array of populations. Notwithstanding this enthusiasm, critical and post-colonial theorists have offered substantial critiques of these initiatives as imposing a neo-liberal paradigm on countries and/or populations that do not fit the definition of 'developed'. In the specific context of sport, several authors have suggested that sport for development and peace is part of a 'hegemonic discourse' that calls for evidence, firmly entrenched in a positivist scientific paradigm, which dismisses alternate forms of knowledge. ${ }^{16}$ Indeed, Global South grassroots practitioner knowledge is often regarded by so-called sport and development professionals as anecdotal information that contributes little or no valid evidence to the field of sport for development. ${ }^{17}$ In this vein, Darnell has employed a Gramscian, Foucauldian and post-colonial theoretical framework to go beyond managerial analyses of the effectiveness of SDP practices to 'ask social questions (i.e., who are the targets of SDP?), political questions (what kind of world view is championed through SDP?) and democratic questions (what inequalities exist and how does SDP respond?)'. ${ }^{18}$

Other scholars have also raised concerns about the problematic 'neo-liberal discourse' pervading UN claims concerning sport. ${ }^{19}$ That said, a number of 
authors have highlighted the benefits of athletics for specific populations. Fountain, for example, has discussed the positive impacts of sport on the behavioural and social development of children, as evidenced by programmes in Rwanda, Burundi and Sudan. ${ }^{20}$ Walseth echoed this view based on her study of young immigrant girls in several geographic locations, including Norway. ${ }^{21}$ However, Gasser and Levinsen have suggested the use of sport to influence behaviour can be a double-edged sword: 'A complicated picture emerges: in some situations sport contributes to social harmony, and in others it feeds conflict. ${ }^{22}$ Studying children in war-torn communities, these authors explored the practice of 'openfun football schools' (OFFS) in reintegrating divided areas following conflict. In the case of Bosnia-Herzegovina, they observed: 'OFFS is based on the concept of "fun football," as developed by the Danish Football Association. Their philosophy is derived from the Danish public sport culture that is characterized by a strong local focus, democratic principles, volunteerism, parent support, and the basic principle of "sports for all.",23

Other analysts have emphasized the invaluable role sport can play in disseminating information. Koss and Alexandrova have suggested sports-related interventions can support HIV/AIDS education and prevention. Participants in a round of 'e-debates' several years ago on sport and development noted its potential positive impacts for education and health, when done 'right'. ${ }^{24}$ Meanwhile, critics, including Giulianotti, Toohey, Jarvie and Reid, Platts and Smith, Mutz and Baur and Gasser and Levinsen, have traced sport's legacy as a mechanism of European colonization and argued that it may spark political violence, terrorism and nationalism. Nonetheless, scholars have thus far been reluctant to generalize concerning the possible impacts of sport, instead emphasizing that its benefits are contingent on local circumstances. ${ }^{25}$ Gasser and Levinsen, for example, have contended several key components are necessary for successful 'fun football' programmes, including coaches trained in soccer and peacebuilding, community support for teams and strong relationship building. The latter condition is important, 'to foster relationships between adult trainers, schools, clubs and municipalities that are involved in organizing the school, and potentially even spectators (presumably mostly parents) from antagonistic communities'. ${ }^{26}$ Carrying this notion further, these authors also have stressed the importance of those employing sport as a development or peace strategy possessing 'intimate knowledge of their own terrain and its particular risks and advantages'. ${ }^{27}$

Other scholars have also observed a need for contextual knowledge if sport is to play a role in development or peacebuilding. Finn and Giulianotti, for example, have argued sport is highly situational. ${ }^{28}$ Their review of football practices raised important issues concerning the role of difference and identity in the efficacy of sport as a development or conflict amelioration strategy. Citing Rorty's revival of the term 'sentimental education' as a descriptor of efforts to secure the citizenry's acculturation to support for human rights, Giulianotti, has argued that sport can play a positive role in 'conflict zones, to promote rehabilitation and reconciliation'. He has also suggested, 'Sport arguably provides for cross-cultural encounters with the other, forcing us into bodily and normative dialogue with 
those that we might find "irrational" or culturally abominable. ${ }^{29}$ In his analysis of UNOSDP programmes, Kidd characterized 'SDP (as a) timely, progressive impulse, one of the most encouraging initiatives in sport in the last few years'. ${ }^{30}$ Yet he also stressed the importance of scale, coordination, training and qualifications of personnel as well as the need to tailor intervention forms to regional needs.

We certainly agree that the significance of sport for peace and development initiatives must be understood and assessed in context. However, we do not focus on specific cases here. We instead build upon recent critical sociological explorations of sport and peacebuilding to explore this practice as part of a marked shift in the political rationality of the United Nations as an international security organization.

Above, we explored how the United Nations and the broader international community have re-conceptualized peacebuilding since 2000 and briefly examined how a share of scholars have considered the role of sport as a part of that project. We next investigate how Foucault conceptualized the concepts of biopolitics and disciplinarity and how these are related to the current prevailing conceptualization of peacebuilding. Thereafter, we outline how sport can be understood as a disciplinary and biopolitical archive.

\section{Peacebuilding as a Disciplinary and Biopolitical Discursive Practice}

The UN Millennium Declaration proposed a significant expansion of the range of issues that would thereafter be subject to international monitoring and intervention. As we noted above, this step resulted in a 'people-centred' international politics and promoted the idea that global security could only be achieved through actions aimed at transforming populations' ways of living together. In 2004, the United Nations High-Level Panel on Threats, Challenges and Change outlined a political rationality of intervention centred on population protection and prevention of threats to those groups. The Panel reconceived international relations as a risk society, threats to that order as shared vulnerabilities and global security as risk management. ${ }^{31}$

The High-Level Panel expanded and redefined the notion of international threat in bio-political terms to include, 'any event or process that leads to large-scale death or lessening of life chances and undermines States as the basic units of the international system'.${ }^{32}$ More specifically, the expert group identified six types of perils, similar in important respects to the six components of human security of the UN Development Programme: economic and social threats (poverty, infectious disease and environmental degradation); inter-state conflict; internal conflict, including civil war, genocide and other large-scale atrocities; nuclear, radiological, chemical and biological weapons; terrorism; and transnational organized crime. ${ }^{33}$ While threats to state security and the stability of the global legal order did not disappear from United Nations' view, they were treated as one of many possible menaces to the well-being of populations with which the world body now had to concern itself. In this view, international safety is achieved by means of an array of techniques aimed at knowing, 
monitoring and successfully addressing a range of dangers, including some created by populations' increased interconnections. As a result, and as we noted above, reforming the way people relate to each other from the 'bottom up' assumed an important place on the security agenda. As noted above, too, Kofi Annan's 2005 proposals for institutional reform marked a clear shift in the goals and sources of legitimacy of the UN as a collective security organization - from states to populations. For Annan, while the United Nations was surely an organization of sovereign states, international security meant populations' security and the concept of 'larger freedom', the organizing idea for UN reform and for bettering the lives of people around the globe, included 'freedom from want, freedom from fear, and freedom to live in dignity'. ${ }^{34}$ In Annan's view, these concerns were inseparably linked and the United Nations had to devise ways and means to address them together. The international body's new attempt to engage a variety of population risk-related issues through integrated security strategies was reflected in the appointment of a 'High Level Panel on SystemWide Coherence' in 2006. Its task was to 'launch work to further strengthen the management and coordination of United Nations operational activities', with special attention to achieving 'internationally agreed development goals', including proposals for 'more tightly managed entities in the field of the environment, humanitarian assistance and development. ${ }^{35}$

In summary, the UN rewrote its scripts concerning how it would conceive and pursue security in the 2000 to 2006 period. Knowledge-intensive strategies aimed at shaping governing processes for living together now became the world body's preferred means of ensuring collective safety. This new framing enlarged enormously the range of issues considered appropriate and necessary for international attention. The United Nations sought to manage population risks it could not oversee alone, but that could only be addressed by integrating and regulating an array of international and local constituencies, including regional organizations, local police, NGOs, for-profit organizations and more. With this shift, international security became biopolitical, that is, the UN began to focus on governing the processes under which populations live together. Attaining human security also became disciplinary because the world body sought to achieve it through intensive performance coordination and assessment of its own and partner workforces and efforts as well as through interventions aimed at creating specific sorts of subjects in conflict societies.

The 2008 Department of Peacekeeping Operations (DPKO) Manual, 'United Nations Peacekeeping Operations - Principles and Guidelines', formalized and operationalized this view of international security as a holistic biopolitical task aimed at reducing civilian vulnerability. ${ }^{36}$ As that document stated, 'the creation of a new United Nations peace building architecture reflects a growing recognition within the international community of the linkages between United Nations peacekeeping, peacemaking and peace building roles. ${ }^{37}$ The 2010 Peace Operations Manual aimed to professionalize and improve the management of peacekeeping and sought to address 'the multi-dimensional nature of contemporary United Nations peacekeeping operations. ${ }^{38}$ It provided a codification of lessons learned as well as systematized action prescriptions for the variety of 
actors involved in peace-related processes. These included not only UN civilian, police and military personnel, but also, as a result of the new security regime, 'regional and other inter-governmental organizations, the range of humanitarian and development actors involved in international crisis management, as well as national and local actors in the countries where United Nations peacekeeping operations are deployed. ${ }^{39}$ The first part of the DPKO operations document described peacekeeping as a 'system of interlocking capabilities' and sought clearly to define and sequence the role of each actor in contributing its capabilities to the 'system'. In the words of Jean-Marie Guéhenno, former Under SecretaryGeneral for Peacekeeping Operations, 'the document (supported) a vision of a system of interlocking capabilities in which the roles and responsibilities and comparative advantages of the various partners (were) clearly defined'. ${ }^{40}$ The Manual defined integrated missions as follows: 'A strategic partnership between a multi-dimensional United Nations peacekeeping operation and the UNCT (United Nations Country Team) based on a shared vision among all United Nations actors as to the strategic objectives of the United Nations presence at country-level. ${ }^{41}$

The clear orientation of this new form of peacekeeping towards assuming biopolitical functions previously the responsibility of national governments was reflected in the Manual's position that durable peace arises from a 'correct' provision of functions of government such as: state ability to provide security; strengthening the rule of law; supporting legitimate political institutions; and promoting social and economic recovery and development. ${ }^{42}$

This overall posture sought to position the UN to oversee populations in conflict societies and to mobilize an array of expert interventions carried out by professional figures aimed at pacifying them when believed necessary. This orientation towards populations in conflict is strikingly similar to how the 'delinquent' was conceived in Foucault's account of classical Europe's disciplinary and prison systems as the subject of a number of savoirs embodied by a variety of professional figures, such as the prison guard, the psychologist, the doctor and the educator, who worked together to achieve broadly shared goals aimed at 'normalizing' such 'deviant' elements.

\section{Exploring Biopolitics and Disciplinarity}

In Foucauldian terms, the UN's redefinition of collective security after 2000 as the well-being of populations suggested the post-cold war international security regime was becoming increasingly biopolitical. For Foucault, biopolitics described the managerial inclination of governments, applied primarily to populations and focused on maintaining the equilibrium of processes of living together. The UN and other international entities' adoption and development of an array of savoirs and regulatory mechanisms targeting people's everyday lives suggested a similar trajectory in international security. International organization security discourses now reflected increasing concern with knowing, managing and protecting the health and wealth of populations under the R2P umbrella. This aspiration converged with a companion need for techniques aimed at 
monitoring, steering and reforming the institutions of disorderly states to encourage their democratization. ${ }^{43}$

Biopolitics has as its goal to reinforce, control, monitor, optimize and organize the forces under it: a power bent on generating forces, making them grow and ordering them, rather than one dedicated to dominating, impeding or destroying them. ${ }^{44}$ International security organizations sought to promote populations' well-being as an element of conditionality and a universal benchmark to be achieved by all states. Protecting populations from gross violations of human rights became a necessary condition for states to exert full sovereignty and a key requirement for admission into supranational political organizations, such as the European Union.

For Foucault, disciplinarity involved taking steps to change individuals with a view to normalization of their deviant elements through techniques that include training, counselling, codification of governmental procedures, surveillance and periodic reporting. Foucault also suggested that disciplinarity constitutes a specific imaginary in the name of which elements perceived as disorderly are to be 'reformed'. Disciplinary methods originated as strategies to increase the usefulness of the human body in institutions, especially the military, and subsequently became a more generalized technique of modern power. Disciplinarity employs a mix of coercion, supervision of processes (rather than results) exercised through partition and control of space, time and movement. It is correctional. Disciplines are the techniques by which individuals are brought to behave according to desired norms.

In Foucault's view, discipline was not only repressive, but also productive. It articulates functions and creates effective processes of activity. It organizes 'cells', 'places' and 'ranks'. Discipline, 'creates complex spaces, at once architectural, functional and hierarchical'. ${ }^{45}$ By establishing partitions, functions, rules and hierarchical architectures, discipline creates structures within which individuals are interchangeable and in which each is defined by their respective positions within the functional space. It perfects movement and coordination among different elements through training. We next explore how the United Nations political rationality for adopting sport as a tool for peacekeeping and peacebuilding reflected biopolitical and disciplinary trajectories.

\section{Sport as a Biopolitical and Disciplinary Enterprise}

Sport as a peacebuilding strategy is biopolitical because it aspires to change people's ways of living together. It is also a disciplinary technique applied to human bodies with a view to transforming 'the souls' of individuals and moulding 'unruly' subjects into 'good citizens'. It relies heavily on training and when employed in peacebuilding it seeks to coordinate different actors with the aspiration of changing those implicated in current or potential conflict into 'normally' functioning members of their societies.

The United Nations clearly situated sport as a biopolitical undertaking in the context of the Millennium Declaration's reconceptualization of peacebuilding. 
UN resolution 67/17 of 28 November 2012, for example, outlined the virtues of sport as a biopolitical tool for making peace:

Recognizing the potential of sport ... as declared in the 2005 World Summit Outcome, to foster peace and development and to contribute to an atmosphere of tolerance and understanding, and reaffirming that sport is a tool for education that can promote cooperation, solidarity, social inclusion and health at the local, national and international levels, as declared in the outcome document of the high-level plenary meeting of the General Assembly on the Millennium Development Goals.

Indeed, the earlier 2003 Report of the United Nations Inter-Agency Task Force on SDP had emphasized similar projected benefits, noting that, 'When these positive aspects of sport are emphasized, sport becomes a powerful vehicle through which the United Nations can work towards achieving its goals. ${ }^{46}$

The 2003 Task Force reinforced the concept of sport as a biopolitical intervention at the local level while reiterating a long-standing argument that sport constitutes a 'human right'. ${ }^{47}$ But it is not merely casual, spontaneous play, nor the practice of sport, that the group found significant. Describing athletics as an 'effective element in community-based initiatives', the report suggested that not just any sporting initiative would serve the goals of sustainable peace. Instead, it advised that sport may play a role in transforming disorderly elements of society and building 'peace-prone subjects' endowed with both ethical qualities of honesty and empathy and with the ability to abide by rules, '[w]ell crafted sports activities teach respect, honesty, communication, cooperation, empathy, and how and why to adhere to rules'. ${ }^{48}$ Rather than leaving these aspects of sporting activities to chance, the Task Force contended that the UN could play an active role in ensuring their effective implementation: 'The United Nations has the ability to help Governments and communities harness the positive aspects of sport and channel them in a coordinated way towards the pursuit of the MDGs. ${ }^{49}$

Special Adviser to the UN Secretary-General Wilfried Lemke, Director of the UNOSDP, declared a 'whole new era with the launch of a new Youth Leadership Programme in 2012 (YLP)' with both emancipatory and rehabilitative goals:

With the launch of this Programme, we intend on the one hand to assist young women and men around the world by giving them a chance to move forward in their personal and professional development and on the other hand to assist their local communities in achieving global development goals through sport. Through this initiative, I hope to create a large group of connected young people from disadvantaged communities that can act as role models and change-makers in their local communities. ${ }^{50}$

The core of the YLP is a 12-day training programme, in which ' 30 young men and women between 18 to 25 years old' come together to learn about the potential positive benefits of sport. It returns youth to their home communities, equipped with: 'a toolkit of methods and ideas for using sport to create positive change'. ${ }^{51}$ The special adviser highlighted the ostensible success of this venture 
by quoting a YLP participant: 'All the activities took me closer to learning new skills including how to improve my programme design, teach peace reconciliation and social engagement and I learned how to include people with disabilities into my programme. 52

The 2012 annual UNOSDP office report emphasized the supposed tool-like and technical nature of sport, touting the release of a new document, 'Sport for Development and Peace: Mainstreaming a Versatile Instrument'. ${ }^{53}$ This text called for an 'action plan' for governments and communities, with 'instructions on how to maximize resources and harness the potential of sport for the promotion of human rights and the achievement of inclusive and sustainable development, including the MDGs, and peace-building objectives. ${ }^{54}$ For the UN, sport is no longer play, but a serious venture with toolkits, training and instructions that aim to remake those who participate in it.

This sort of biopolitical investment on the United Nations' part requires constant tending, not so much in the form of financial support as by means of guidance, regularly submitted to member governments. In 2008, for example, the International Working Group for SDP released a report, 'Harnessing the Power of Sport for Development and Peace: Recommendations to Governments' that emphasized 'well-designed programmes that prioritize the best values of sport' and recommended ways that governments could employ sport as a tool that could be integrated 'into national and international development policies and programs'. ${ }^{55}$ Most recently, and on the basis of the UN example, the British Commonwealth Secretariat released The Commonwealth Guide to Advancing Development through Sport, announcing its intent to 'take development through sport to the next step. ${ }^{56}$ This effort was advertised as 'an intelligent digest' and professed to advise member governments on 'how they can frame inclusive, workable policies and plan, conduct, and monitor and evaluate accessible, effective programmes. $^{57}$

\section{Conclusions}

The UN narrative concerning sport and peacebuilding traced here evidences both biopolitical and disciplinary trajectories. Sport in peacebuilding is biopolitical because as a technique it aims to change people's ways of living together from conflict-prone to peaceful in order to achieve order and stability. It is disciplinary because it is employed in a strategy that views social change as the result of individually crafted interventions that reform 'the souls' of disorderly individuals by training their bodies and enhancing their overall ability to coordinate with others in order to produce desired results. Foucault argued that disciplinary methods originated as ways to increase the usefulness of the human body in institutions, especially the military, and subsequently became a more generalized technique for governing societies. Sport as a tool for peacebuilding seeks to create subjects that are at once 'docile', that is, able to follow 'the rules of the game' or to adopt desired social norms and 'productive', that is, able to make positive contributions to a group or to society, and particularly to conflict amelioration. Discipline is the result of careful design and requires adroit planning and 
implementation. Disciplinarity results in standardization because it trains populations with a view to achieving a set of benchmarks as well as individualization, because each subject (or each athlete) must be corrected, treated and assessed individually to enhance his or her performance. Sport as a technique for peacebuilding is situated within practices aimed at maintaining and fostering an international order that encompasses social engineering processes that are capillary, decentralized and increasingly centred on reforming individuals and society. ${ }^{58}$ Along with adopting a new conceptualization of international dangers as the proliferation of multifarious and dispersed threats in recent years, the United Nations has also devised a number of mechanisms of control and reformation that go beyond institution building and instead target populations directly. New millennium discourses of security made populations central, both as victims and as perpetrators of menace. In the face of the failure of efforts in the 1990s to bring about peace and development through state institution reforms, and after the $11 \mathrm{Sep}$ tember 2001 attacks refocused attention on non-state actors as sources of threat, risk management became an increasingly accepted framework by which to organize and ensure collective security. ${ }^{59}$ However, effective risk management demands holistic and preventative approaches. ${ }^{60} \mathrm{~A}$ variety of issues, including poverty, diseases and social deprivation, converged into discourses of international security. Promoting social well-being through youth population reform became a prominent concern, for which sport became one possible solution. This expansion of peacebuilding's scope invited the active interest and involvement of a multiplicity of constituencies. A cluster of actors today often overseen or coordinated by the United Nations, now share the task of transforming and reforming citizenries from conflict prone to peace minded. These players include, in addition to the United Nations, national governments, NGOs, local communities and so on. Very similar to the way in which Foucault described disciplinarity in classical Europe, the 'delinquent' (or individual engaged in conflict) becomes the subject of a number of savoirs embodied by a variety of professional figures, such as coaches, league officials and government actors and educators, who work together with similar strategies to achieve broadly shared goals to normalize the deviant elements.

This article has assessed the role of sport in peacebuilding as part of a biopolitical and disciplinary political rationality adopted incrementally by the United Nations and the international community since 2000. In assuming this posture, the UN widened its focus from seeking to reform state institutions to working to transform the populations of conflict societies. It aimed to do so by targeting individuals and changing their ways of living together through an array of disciplinary and biopolitical techniques enacted by a loosely coordinated array of actors. The effectiveness of these mechanisms in achieving their stated goals has been uneven, however, and cannot be assessed in the abstract, but only in the specific context of their implementation. Notably, all outcomes of such initiatives are mediated by the actions of many actors beyond the formal control of the United Nations. However consequential sport may be as a conflict management or peacebuilding biopolitical and disciplinary strategy, its success and the effects it may have on individuals and communities can never be assumed in 
the abstract. We embrace Coalter's scepticism concerning the claims of what he has called 'sports for development evangelists and conceptual entrepreneurs', ${ }^{61}$ while sympathizing with his admiration for the 'optimism of the will' of many practitioners. Our goal here is to scrutinize the assumptions of this practice, to challenge the often superficially appealing and appeasing oversimplifications that go with it, and to call for a reflective attitude and contextualized assessments when sport is employed as a peacebuilding strategy.

\section{ACKNOWLEDGEMENTS}

The authors wish to acknowledge and thank Daniel Messplay for his research assistance in the development of this article.

\section{ABOUT THE AUTHORS}

Dr. Laura Zanotti is an Associate Professor of Political Science at Virginia Tech. Her research interests include critical political theory as well as international organizations, UN peacekeeping and NGOs. She is the author of Governing Disorder: United Nations Peace Operations, International Security, and Democratization in the Post Cold War Era (Penn State University Press, 2011). She published in numerous leading academic journals. Zanotti has also co-authored and co-edited two books (with Max Stephenson), entitled Peacebuilding through Community-Based NGOs: Paradoxes and Possibilities, Kumarian, 2012 and Building Walls and Dissolving Borders (see below). Prior to joining Virginia Tech Laura has worked for a decade at the United Nations.

Dr. Max Stephenson Jr., Professor of Public and International Affairs at Virginia Tech, also serves as Director of the Virginia Tech Institute for Policy and Governance. His current research interests include peacebuilding, democratization and development and community change processes. Professor Stephenson has published several books. His latest book, Arts and Community Change: Exploring Cultural Development Policies, Practices and Dilemmas, ed. with Scott Tate, Oxford, U.K: Routledge Publishers will be published in 2015.

Dr. Marcy Schnitzer, Research Associate at the Institute for Policy and Governance, is also Associate Dir. for Strategic Planning and Improvement in Virginia Tech's Office for Diversity and Inclusion. Marcy's research is on counterpublics in the transnational public sphere. She has also published research on humanitarian and disaster relief coordination. Dr. Schnitzer has more than 15 years experience working with diverse communities, and negotiating community-university partnerships.

\section{NOTES}

1. Fred Coalter, Sport for Development: What Game Are We Playing?, Abingdon: Routledge, 2013.

2. Ibid., p.3.

3. United Nations General Assembly, Millennium Declaration, 8th plenary meeting, 8 Sept. 2000, 55/2 (at: www.un.org/millennium/declaration/ares552e.htm). For UN documents on the Responsibility to Protect, see www.responsibilitytoprotect.org/index.php/document-archive/unitednations.

4. See Béatrice Pouligny, Peace Operations Seen from Below: UN Missions and Local People, London: C. Hurst, 2006; Roger Mac Ginty, International Peacebuilding and Local Resistance: Hybrid Forms of Peace, London: Palgrave Macmillan, 2011; Oliver Richmond, A Post-Liberal Peace, London: Routledge, 2011.

5. Michel Foucault, The Foucault Effect: Studies in Governmentality, Hempstead: Harvester Wheatsheaf, 1992.

6. Michel Foucault, The Archaeology of Knowledge, trans. A.M. Sheridan Smith, London: Routledge, 1972. 
7. Ingrid Beutler, 'Sport Serving Development and Peace: Achieving the Goals of the United Nations through Sport', Sport in Society, Vol.11, No.4, 2008, pp.359-69.

8. United Nations, 2005, World Summit Outcome, A/60/L.1 of 15 Sept. 2005 (at: www.unis. unvienna.org/pdf/A60L.pdf).

9. United Nations Inter-Agency Task Force on Sport for Development and Peace, 2003, 'Sport for Development and Peace: Towards Achieving the UN Development Goals' (at: www.un.org/wcm/ webdav/site/sport/shared/sport/pdfs/Reports/2003_interagency_report_ENGLISH.pdf).

10. Ibid.

11. Beutler (see n.7 above).

12. United Nations Inter-Agency Task Force on Sport for Development and Peace (see n.9 above), pp.21-2.

13. United Nations General Assembly, 61st Session, Report of the Secretary-General, 'Sport for Development and Peace: The Way Forward', 26 Sept. 2006 (06-53114 (PubMed E) 061006) (at: www.un.org/wcm/webdav/site/sport/shared/sport/pdfs/SG\%27s\%20Reports\% 20to\%20GA/A-61-373/A-61-373_EN.pdf).

14. United Nations General Assembly, 'The Millennium Development Goals Report', 2006 (at: www.un.org/zh/millenniumgoals/pdf/MDGReport2006.pdf).

15. Since 2004 the United Nations has produced seven reports on sports for development and peace. From newest to oldest they are: A/67/282, 'Sport for Development and Peace: Mainstreaming a Versatile Instrument', 9 Aug. 2012; A/65/270, 'Sport for Development and Peace: Strengthening the Partnerships', 9 Aug. 2010; A/63/466, 'Sport for Development and Peace: Building on the Foundations', 3 Oct. 2008; A/62/325, 'Sport for Development and Peace: Progress and Prospects', 12 Sept. 2007; A/61/373 'Sport for Development and Peace: The Way Forward', 22 Sept. 2006; A/60/217, 'Sport for Peace and Development: International Year of Sport and Physical Education', 11 Aug. 2005; A/59/268, 'Sport for Peace and Development: International Year of Sport and Physical Education', 27 Oct. 2004.

16. Simon C. Darnell, 'Power, Politics, and "Sport for Development and Peace": Investigating the Utility of Sport for International Development', Sociology of Sport Journal, Vol.27, No.1, 2010, pp.54-75, p.71.

17. Sara Nicholls, Audrey R. Giles and Christabelle Sethna, 'Perpetuating the "Lack of Evidence" Discourse in Sport for Development: Privileged Voices, Unheard Stories and Subjugated Knowledge', International Review for the Sociology of Sport, Vol.46, No.3, 2011, pp.249-264 (first published on September 23, 2010, p.2).

18. Simon Darnell, Sports for Development and Peace: A Critical Sociology, London: Bloomsbury Academics, 2012, p.4.

19. Lyndsay M.C. Hayhurst, 'The Power to Shape Policy', International Journal of Sport Policy, Vol.1, No.2, 2009, pp.203-27.

20. Susan Fountain, 'Peace Education in UNICEF', Working Paper, New York: UNICEF, 1999.

21. Kristin Walseth, 'Bridging and Bonding Social Capital in Sport: Experiences of Young Women with an Immigrant Background', Sport, Education and Society, Vol.13, No.1, 2008, pp.1-17.

22. Patrick Gasser and Anders Levinsen, 'Breaking the Post-War Ice: Open Fun Foot-Ball Schools in Bosnia and Herzegovina', Sport in Society, Vol.7, No.3, 2004, p.457.

23. Ibid., p.462.

24. J. Koss and A. Alexandrova, 'HIV/AIDS Prevention and Peace through Sport', The Lancet, Vol.366, No.2, 2005, pp.S3-S4; International Platform on Sport and Development e-Debate 1, Oct.-Dec. 2009 (at: www.sportanddev.org/en/newsnviews/sportanddev_e_debates/sport development_e_debate/results_of_the_e_debate/round_1/).

25. Richard Giulanotti, 'Sport and Social Development in Africa: Some Major Human Rights Issues', the First International Conference on Sports and Human Rights, Sydney, Australia, 3 Sept. 1999; Kristine Toohey, 'Terrorism, Sport and Public Policy in the Risk Society', Sport in Society, Vol.11, No.4, 2008, pp.429-42; G. Jarvie and I.A. Reid, 'Sport, Nationalism and Culture in Scotland', The Sports Historian, Vol.19, No.1, 1999, pp.97-124; Andy Smith and Chris Platts, 'The Independent European Sport Review: Some Policy Issues and Likely Outcomes', Sport in Society, Vol.11, No.5, 2009, pp.583-97; Michael Mutz and Jürgen Baur, 'The Role of Sport for Violence Prevention: Sport Club Participation and Violent Behaviour among Adolescents', International Journal of Sport Policy and Politics, Vol.1, No.3, 2009, pp.305-21; Gasser and Levinsen (see n.22 above); International Platform on Sport and Development e-Debate 1 (see n.24 above). An extensive body of literature exists concerning cricket in this regard. For examples see A. Appadurai, Modernity at Large, Minneapolis, MN: University Minnesota Press, 1996; N. Mannathukkaren, 'Subalterns, Cricket and the Nation: The Silences of "Lagaan"', Economic and Political Weekly, Vol.36, No.49, 8-14 Dec. 2001, pp.4580-8; Boria Majumdar and Sean 
Brown, 'Why Baseball, Why Cricket? Differing Nationalisms, Differing Challenges', International Journal of the History of Sport, Vol.24, No.2, 2007, pp.139-56.

26. Gasser and Levinsen (see n.22 above), p.463.

27. Ibid., p.467.

28. Gerry P.T. Finn and Richard Giulianotti, Football Culture: Local Conflicts, Global Visions, London: Routledge, 1999.

29. Richard Rorty, 'Human Rights, Rationality and Sentimentality', in S. Shute and Susan Hurley (eds), On Human Rights: The Oxford Amnesty Lectures, New York: Basic Books, 1994, pp.111-34; Richard Giulianotti, 'Human Rights, Globalization and Sentimental Education: The Case of Sport', Sport in Society, Vol.7, No.3, 2004, p.366.

30. Bruce Kidd, 'A New Social Movement: Sport for Development and Peace', Sport in Society, Vol.11, No.4, pp.370-80, 2008, at p.376.

31. United Nations General Assembly, 'A More Secure World: Our Shared Responsibility', Report of the High-Level Panel on Threats, Challenges and Change, UN doc., A/59/565, 2004.

32. United Nations General Assembly, 'In Larger Freedom: Towards Development, Security and Human Rights for All', A/59/2005 (at: www.un.org/largerfreedom/).

33. See United Nations Development Programme (UNDP), Human Development Report 1994: New Dimensions of Human Security, Oxford: Oxford University Press, 1994, and United Nations General Assembly (see n.31 above).

34. United Nations General Assembly (see n.32 above).

35. See United Nations, 'High Level Panel on System-Wide Coherence', 2006 (at: www.un.org/ events/panel/html/page2.html).

36. United Nations Department of Peacekeeping Operations, United Nations Peacekeeping Operations - Principles and Guidelines, New York, NY: Peacekeeping Best Practices Section, Division of Policy, Evaluation and Training. Department of Peacekeeping Operations, United Nations Secretariat One UN Plaza, 2008, p.20.

37. Ibid., p.20.

38. Ibid., pp.6, 15.

39. Ibid., p.10.

40. Ibid., p.8.

41. Ibid., p.96.

42. Ibid., p.25.

43. In the last decade an increasing number of scholars have explored peacebuilding through Foucauldian lenses. For a critique of liberal security regimes see M. Dillon and J. Reid, The Liberal Way of War: Killing to Make Life Live, London: Routledge, 2009; W. Larner and W. Walters, Global Governmentality: Governing International Spaces, Advances in International Relations and Global Politics, London: Routledge, 2004; Laura Zanotti, Governing Disorder: UN Peace Operations, International Security, and Democratization in the Post-Cold War Era, University Park, PA: Pennsylvania State University Press, 2011. For a more specific critique on NGOs, see M.R. Duffield, Development, Security and Unending War: Governing the World of Peoples, Cambridge: Polity, 2007; M.R. Duffield, Global Governance and the New Wars: The Merging of Development and Security, London: Zed Books, 2001.

44. Michel Foucault, The History of Sexuality: An Introduction (Vol. 1), New York: Vintage Books, 1990, p.136.

45. Michel Foucault, Discipline and Punish: The Birth of the Prison, 2nd edn, New York: Vintage Books, 1995, p.148.

46. United Nations Inter-Agency Task Force on Sport for Development and Peace (see n.9 above), p.v.

47. Ibid. The report specifically cited the following: UNESCO International Charter of Physical Education and Sport, 1978, see especially article 1, which states: 'The practice of physical education and sport is a fundamental right for all'; UNICEF Convention on the Rights of the Child, 1990, see especially article 31, which states: 'The practice of physical education and sport is a fundamental right for all'; Declaration on the Rights of the Child, 1959, see especially principle 7, which states: 'The child shall have full opportunity for play and recreation, which should be directed to the same purposes as education; society and the public authorities shall endeavour to promote the enjoyment of this right', p.27.

48. United Nations, 2004 (see n.15 above), p.4.

49. United Nations Inter-Agency Task Force on Sport for Development and Peace (see n.9 above), p.3.

50. United Nations Office of Sport for Development and Peace, 2012, 'Youth Leadership Programme', Doha, Qatar, p.4. 
51. Ibid., pp.4, 23.

52. Ibid., p.23.

53. United Nations Office of Sport for Development and Peace, A/67/282 (see n.15 above), p.9.

54. Ibid., p.9.

55. United Nations Sport for Development and Peace International Working Group, website. Reports and Publications webpage (at: www.un.org/wcm/content/site/sport/home/unplayers/ memberstates/sdpiwg_keydocs).

56. Tess Kay and Oliver Duffield, The Commonwealth Guide to Advancing Development through Sport, London: Commonwealth Secretariat, 2013.

57. Sport for Development and Peace International Working Group (see n.55 above).

58. Zanotti (see n.43 above).

59. Ibid., p.60.

60. Ulrich Beck, Risk Society: Towards a New Modernity, London: Sage, 1992.

61. Coalter (see n.1 above), p.3. 